\title{
TEACHING COUNSELING STUDENTS TODAY
}

\section{INTRODUCTION}

Are doctoral students prepared to fulfill the multifaceted role of counselor educator upon graduation? According to Elliott et al. (2019) and our own personal experiences, the answer is no, they are not fully prepared for the role of counselor educator. Elliott et al.'s (2019) study explored intentional pedagogical training in counselor education doctoral programs. The doctoral student participants' experiences mimics our experiences in that they shared feelings of fear and self-doubt, incongruence within the teaching role, and various levels of unpreparedness. No doctoral program can fully prepare new counselor educators for the ever-evolving roles and responsibilities of this profession. Hopefully, this chapter and the following ones can fill in the gaps.

Some counselor education doctoral programs prioritize training either effective educators or researchers. The focus usually aligns with the emphases of the university that supports those doctoral programs. It is known that current faculty promotion and tenure criteria strongly emphasize teaching over scholarship (Baltrinic, Jencius, \& McGlothlin, 2016; Barrio Minton, Wachter Morris, \& Yaites, 2014; Orr, Hall, \& Hulse-Killacky, 2008). This shift is also reflected in the 2016 Council for Accreditation of Counseling and Related Educational Programs (CACREP) standards, where there is more importance placed on 
training doctoral students in instructional theory and pedagogy (CACREP, 2001, 2009). In fact, the 2016 CACREP standards plainly state that counselor education doctoral students must develop a professional identity related to teaching practices and responsibilities (CACREP, 2015a, Section 6.B.3). The caveat to this emphasis is that the CACREP standards are designed for programmatic flexibility. Training graduates who are highly effective teachers is not standardized across counselor education programs. Therefore, there is no way of knowing how effectively doctoral programs are prioritizing this component of their students' development (Malott, Hall, SheelyMoore, Krell, Cardaciotto, 2014).

Despite which facet of education, research, or teaching a program prioritized, we have imagined that if you picked up this book, you are passionate about training counselors. You want to be effective but feel overwhelmed at times by the demands and responsibilities of a counselor educator. You should feel pressure; after all, the state of the counseling field and the mental health of generations rest upon your students' decisions in critical moments in session and their ability to build strong therapeutic relationships. When it sank in, when the gravity of our responsibility as counselor educators washed over us, it gave us pause. Everything we do and say in this role has ripple effects in the communities our students serve.

This book may be picked up at various stages of a counselor educator's career. Readers may be doctoral students in their first doctoral-level teaching course. They may have just graduated from a doctoral program in counselor education and supervision or a related field, bagged the first faculty position, and received the teaching assignments for the first semester. Or maybe readers are veteran professors with tenure, great teaching evaluations, and a bookshelf of awards and books, but who may occasionally feel off their game. However readers found their way to this book and this chapter, our hope is that by the end they gain a more enriched understanding of 
the contexts in which they are training students and the world they are preparing students to serve.

\section{OVERVIEW OF INSTITUTIONS OF HIGHER EDUCATION}

Universities are like Russian dolls. There is a community that engulfs a university (e.g., Arsenal University). Within Arsenal University there are multiple colleges (e.g., College of Education), which engulf programs (e.g., Counseling Program), which further engulf individual faculty members (e.g., Dr. Thierry Henry), who support students (e.g., Ian Wright). They are all nestled within one another and affect each other immensely. Our experience as counselor educators, and perhaps yours too, is that big decisions about the university are like a fog that slowly seeps into our offices. We find ourselves asking"When did we start doing it that way?" quite often.

Counselor educators may have accepted a position under the pretense that they have to publish only 8 to 12 articles in 5 years to keep their jobs. Then during the second semester, those counselor educators hear that they now need 12 to 15 published articles in top-tier journals. Then, a couple more months pass, and that number jumps to 15 to 20. And they risk losing their jobs unless awarded a grant. The counselor educators may then have to move themselves and their families to their next job. Sometimes counselor education can be a transient field. The system is not perfect. Training highly effective clinicians is not always the priority of the program or the university.

Decisions such as how much counselor educators publish and where they publish are influenced by stakeholders who have a tremendous influence over the characteristics of a university. There are a great number of universities in the United States, and it is hard to classify these institutions. However, in 1973 the Carnegie Classification of Institutions of Higher 
Education provided ways to differentiate between institutions (Altbach, 2015). Briefly, Altbach (2015) explained that the Carnegie Classification tracks data such as the type and number of degrees awarded, faculty numbers, enrollment numbers, funds generated from intellectual property such as research or book publications, the amount of research projects conducted, and the level of internationalization. According to Okech and Rubel (2018), there are different types of institutions within the Carnegie Classification: Research Intensive and Others, Teaching Intensive and Others, and Traditional Online and Hybrid.

\section{COUNSELOR EDUCATION}

As counselor educators, we belong to a unique profession that closely relates to the evolution of the counseling profession. We, like clinicians, are supported by professional organizations, but ours are focused on training counselors: the Association for Counselor Education and Supervision (ACES) and the CACREP. The enduring advocacy by the ACES on behalf of counselor educators and supervisors has led to the development of standards for counselor preparation (ACES, 1979, 2014) and counseling programs (CACREP, 2015b). The heart of the ACES lies in the advancement of the counseling profession through counselor education and supervision (ACES, n.d.). Since its inception, the CACREP aimed to "provide leadership and to promote excellence in professional preparation through the accreditation of counseling and related educational programs" (CACREP, 2020).

Today, the CACREP standards shape the counselor education curriculum, which means that the CACREP has a significant influence over who we are as counselors and counselor educators. Counselor training programs are given a certain amount of freedom to meet the CACREP 
standards given the needs of the communities they serve, the culture of their institution, the cultural diversity of their program, and other factors.

The role of a counselor educator stretches well beyond the responsibilities of instruction. Counselor educators wear many hats while maintaining their role and responsibilities. They are asked to advise, mentor, gatekeep, administrate, serve both the professional and local communities, supervise, teach, and be part of many other activities. The position comes with a variety of nebulous relationships and stressors that doctoral students and new faculty members may feel unprepared to manage (Magnuson, 2002).

If we were new faculty members again, we would have asked to see the program's previous CACREP SelfStudy Report. This report is a comprehensive overview of the counseling program. It includes narrative responses and supporting documentation that show how the program is meeting the CACREP standards. We would have read through the self-study and the current program handbook. We would have created a list of questions about the program and met with our department chair to talk through the program. Doing these things would have given us a better understanding of how the program operates and how we can best serve it.

\section{Teaching Is Hard}

Teaching counselors is hard because of its layered complexity. One minute counselor educators are using counseling skills in class, then supervising, then writing and conducting research, then presenting at a conference, then serving the community (maybe they have a small private practice), and then handling student concerns; or a clinical site is violating their supervision contract; or the CACREP report is due; or a supervisee needs to 
speak to a detective about his or her client. Each day is different, and managing this complexity comes with experience.

Perhaps the existence of transferable skills, or lack of it, between counseling and counselor educating is also hard. Counselor training, and to some extent counselor education training too, did not prepare me to impart vast amounts of information while attending to different student cultures and learning styles, assessing students' clinical skills and other work, and providing personalized feedback. If readers are like us at the beginning of their careers, they may have felt like an impostor. Like us, readers may be millennials, the youngest faculty members in their program and among the youngest in the university. This may cause readers to think, "I hope they don't figure out I am only one class day ahead of them in the reading."

We have found, like in our counseling work, we are most successful when we bring all of who we are into the room, build a strong therapeutic relationship, and relate the coursework to the lives of our students. Palmer (2017) reminds us that "bad teachers distance themselves from the subjects they are teaching-and in the process, from their students. Good teachers join self and subject and students in the fabric of life" (p. 11). Training counselors is hard because we are working with adults who have trauma, triggers, flaws, and strengths.

\section{Common Theories of Teaching and Learning}

In counseling, our theoretical orientation guides our work. This is true for the educational theory we choose to be the undercurrent of our teaching. In our experience, choosing a teaching theory that aligns with our counseling approach helped us feel more congruent in the classroom. Choosing a teaching theory also mimics the 
process of choosing a counseling theory; it takes time and patience. There are many theories of teaching and learning, and they are constantly evolving. We do not cover all of them, but only the seminal works within the extant literature.

\section{Constructivism}

A major principle of this theory is that the learner is an information constructor. The learning process is active and built upon the experiences of the student (McAuliffe \& Eriksen, 2011; Vijaya Kumari, 2014). Students construct their own meaning from the lecture or classroom activities based upon their subjective experiences (Whitman \& Beeson, 2018). There is no universal truth in this perspective. Your role is to help students expand their understanding of reality and construct their own truth. You facilitate an environment where students can use their own skills to solve life's problems. Constructivist educators use dialogue to spark active learning where students grapple with topics from within a social context (Whitman \& Beeson, 2018). Counseling theories are not just words on a PowerPoint presentation for students to memorize to pass their exam. Students experience these theories, filter them through their life experiences, and reflect on what it means for them to understand a concept culturally, spiritually, or relationally. The constructivist perspective aligns with humanistic approaches to counseling. McAuliffe and Eriksen (2011) offer guidance to counselor educators wanting to teach from this perspective. Having known and taught alongside Garrett McAuliffe for a couple of years, I (Jude) saw how he encouraged his students' autonomy and engagement by beginning lectures asking students what they needed, educationally, in order to feel prepared to do their best work. I was struck by the relationship he was able to cultivate between students and the topics they discussed in class. 


\section{Critical Pedagogy}

You may recognize characteristics from this theory from its inspiration: critical theory. According to Freire (2018), educators practicing critical pedagogy focus on power, oppression, injustice, and society in regard to economic, cultural, and political inequality. According to Aliakbari and Faraji (2011), "students should act in a way that enables them to transform their societies which is best achieved through emancipatory education" (p. 77). In our understanding, emancipatory education is an environment where students can question their instructor and the information presented in class. Freire (2018) explained that traditionally, teachings have a monolithic approach to education-teachers are the experts, and students unquestionably comply. The formula in traditional views of education is (a) students receive the teacher's knowledge, (b) memorize, and (c) repeat (Aliakbari \& Faraji, 2011). Critical pedagogy places students in a more active role, where they take in knowledge and then apply it to societal issues such as oppression and racism with the goal to improve society (Freire, 2018). Students have a right to question and be heard (Nixon-Ponder, 1995). There is a sense of equality in the classroom environment, and it is student centered and involves critical thinking and discussions. At the end of the semester, students might say that a course taught from this perspective raises their consciousness and makes them more critical about the world. This theory might align with the feminist approach to counseling.

\section{Transformative Learning}

This theory was created by Mezirow in 1978 and suggests that we learn through the process of changing our frame of reference. Mezirow (2018) explained that individuals create their own frame of reference for the world based on their values, feelings, thoughts, assumptions, and life experiences. Over time, these properties shape 
our perspectives. They are influenced by culture, politics, and education (Mezirow, 2018). These influences are like codes in our minds and make up our point of view. Transformational learning emphasizes critical reflection of this point of view. The code gets updated as we confront the world around us through the topics discussed in class. The challenge for educators using this approach is creating an environment where students feel safe to reflect critically on their assumptions and stereotypes. Mezirow (2018) suggested that educators navigate this challenge by encouraging autonomous and critical thinking and empathic expression of thoughts and feelings. Remaining open to students' perspectives, regardless of our agreement or disagreement, can facilitate this classroom environment.

\section{The Students}

Graduate students learn best when treated like adults. Meaning, counselor educators must respect their time and the sacrifices they make to come to class and complete homework assignments. It is generally assumed that for adult learners, (a) self-concept becomes more self-directed because of maturity, (b) experience is an invaluable resource that informs learning and accommodates new information, (c) readiness to learn is based on performing social tasks more effectively, and (d) orientation to learning is based on present applications instead of future applications (Knowles, 1970). We believe these assumptions to be true for millennial learners too, who make up most graduate counseling courses today.

If readers are like us, they may have found themselves sitting awkwardly in a faculty meeting, the only millennials, discussing ways to better teach millennials. We have heard things like "This generation is so entitled." Are millennials the needy, entitled, selfish brats some older tenured faculty members believe us to 
be? The answer is "maybe," and so is everyone else. In a 2010 study, Stewart and Bernhardt compared millennial students with pre-1987 students. They found that millennial college students experience lower feelings of health and fulfillment, as well as less impulse control (Stewart \& Bernhardt, 2010). They also found that millennial students scored higher on narcissism scales when compared to nonmillennials (Stewart \& Bernhardt, 2010). However, their findings saw an increase in these factors across different student demographics, which led them to suggest that universities may just be admitting greater numbers of less healthy, more impulsive and entitled students in general, regardless of age (Stewart \& Bernhardt, 2010). Gregg (2017) discussed millennial students from a developmental perspective. He suggests that emerging adulthood is a time for self-focus and making independent decisions, sometimes for the first time. From a distance, this learning process can seem like narcissism and impulsivity. We think sometimes professors forget that discernment is a learned trait, and not given to us at birth. And yes, we can admit that we and other members of our generation may have experienced a delayed entry into adult levels of responsibility, which causes us to need more attention at times. However, to blanket a whole graduate classroom with generation characteristics is dangerous.

The danger rests in not acknowledging the full spectrum of diversity within each counseling classroom today. Today's graduate counseling classrooms are more diverse than ever before. For example, some tenured faculty grew up when everyone in their house, on their street, in their neighborhood and city liked similar music. Today, siblings grow up in the same room and have a completely different cultural identity. They may share the same ethnic makeup, but one sibling loves mainstream pop music, while the other may have heard and fallen in love with an obscure comedy acoustic folk duet from New Zealand. One sibling may love golf and the other cosplay. 
The access to information, self-defining experiences, and self-exploration activities are endless today, and our students take advantage of them well before they enter our classrooms. By graduate school, a student may have lived 10 virtual lifetimes, raised digital children, studied black holes, and have had access to answer every single question he or she may have had via his or her computer or cell phone. The challenge is not only respecting the diversity but addressing it in a way that supports all students' learning.

Today's students also face an increasing amount of pressure and concerns from the outside world than previous generations. Consider the cost of a graduate degree in counseling today; some programs range from $\$ 300$ a credit hour to $\$ 900$ a credit hour. Financial burdens can add more significance to their grade on a paper. A lower grade can threaten the sustainability of a small young family. The cost is far more than finical. Students pay in time- time away from their children, partners, parents, and other loved ones. Most nontraditional students live in dual income homes where the student and the partner work tirelessly to run their family while meeting the demands of a sometimes-empathetic course instructor. We have seen students who gave birth a week ago and are back for the next class. I (Jude) have had a student have a minor heart attack, the third one, and missed only two classes. We have seen students who are school teachers who also drive for Uber at the end of their school day and before our class starts. There are also students who struggle to participate in class because they are the primary caregiver for their child with special needs and aging parents. The sacrifices students make to pay this cost, in our opinion, give them the right to expect a certain level of training. These students need empathy, not sympathy. Empathy can support the energy they need to thrive in graduate school.

In addition to financial burdens, some students, especially those belonging to marginalized populations, 
face an increased threat to their lives and emotional well-being. Today's students come to class after a long day of facing microaggressions, exhaustive code switching, racism, sexism, gaslighting, and a host of other spirit-pounding interactions. Our class topics can be triggering depending upon students' lived experiences. Why would they not be exhausted by the time they make it to class? Why would they not be triggered by a discussion on privilege? We all know that students getting triggered is not a new phenomenon in counseling classrooms, but today's students are more aware of current issues; some can be more connected to these issues, which means that counselor educators have to stay abreast of current issues as well. Consider the current political climate. For readers who, like us, taught a class on the day after the 2016 presidential election, you know how much of an impact current issues have on students' development. Most of my classes postelection turned into a partisan group process where students from all political and religious affiliations shared their hearts. Again, after the "Kavanaugh hearing," we spent time in our practicum and internship classes discussing how the hearings influenced our students and their clients. It is more than technology and the Internet that influence today's students. They seem to be more connected to personal, community, and global issues. To connect with these students, we as counselor educators need to teach with this in mind.

\section{What Do We Know About Counselor Development?}

We know that counselor development is a gradual process where counselors move from relying on external authority to internal authority over a long period of time (Skovholt \& Ronnestad, 1992). We also know that while training in graduate school has a great impact on counselor development, continued training after graduation and throughout a counselor's career may have an even 
greater impact (Skovholt \& Ronnestad, 1992). You may already recognize the names Skovholt and Ronnestad from your readings about counselor development. They completed a seminal research project in 1992 identifying a stage model of counselor development. They also included themes related to counselor development.

In that study, Skovholt and Ronnestad (1992) identified eight stages of counselor development over the course of a long career. Those stages include (a) conventionaluntrained professional using what one naturally knows, (b) transition to professional training-first-year graduate students who are working to assimilate a vast amount of information and apply it to practice, (c) imitation of experts-middle graduate school years where students maintain a meta-level openness but are uncertain while developing a mastery of the basics, (d) conditional autonomy-internship students who are functioning as professionals with variable confidence, (e) explorationnew graduates who are anxiously modifying externally imposed professional styles, (f) integration-2- to 5-year postgraduates who are developing authenticity, (g) individuation-characterized by a deepening of authenticity as wisdom and experience is accumulated, and $(h)$ integrity-counselors are being themselves and preparing for retirement.

Skovholt and Ronnestad (1992) went on to discuss 20 themes related to counselor development. While they are all important, we choose the themes we believe to be particularly poignant to the larger discussion within this chapter. One theme within their research states, "Professional development is growth toward professional individuation" (Skovholt \& Ronnestad, 1992, p. 507). Counseling students are constantly striving to integrate their personal and professional selves. Counselor educators must facilitate a classroom experience that sparks reflection upon these two parts of students as they grow. The next theme aligns with the previous statement: "As the professional matures, continuous professional 
reflection constitutes the central developmental process" (p. 509). They went on to discuss what is involved in professional reflection: intense personal and professional experiences, open and supportive work environment, and a reflective stance. Another notable theme suggests that "development is influenced by multiple sources that are experienced in both common and unique ways" (p. 511). This theme parallels what has been found to work in therapy.

According to Duncan, Miller, Wampold, and Hubble (2010), 40\% of what works in therapy are client variables and extra-therapeutic events that are out of the therapist's control. Counseling graduate students are trained outside of the classroom as well as inside. As educators, we simply try not to allow their education to get in the way of their education. For example, as practicum students, we needed to process case after case, sharing insights and sometimes even dumping our lived experience. We felt our education getting in the way of our education when our instructor needed to discuss that day's journal article topics and book chapters that may not have been related to our caseload. This brings us to our next theme: "Clients are a continuous source of influence and serve as primary teachers" (Skovholt \& Ronnestad, 1992, p. 512). The old counseling adage is correct: We get the clients/students we need. The universe has an interesting way of knowing which personal issues you have yet to resolve, and it pumps your caseloads and classrooms full of people who force you to confront those issues. Growth in some way is unavoidable when we use built-in teaching tools such as our students' clinical experiences. The last theme explains that "extensive experience with suffering produces heightened tolerance and acceptance of human variability" (Skovholt \& Ronnestad, 1992, p. 514). This means: make your students suffer for their own good! Seriously, the researchers explained that mistakes and suffering in some form are an inherent part of life. As counselor educators, it may be beneficial to lean into this 
lived experience in class, making lectures and activities experiential and focused on acclimating students to the suffering they will hear in their work.

\section{How Do They Learn?}

There are as many ways to learn as there are people on Earth. The past 20 years have seen an increase in research regarding the way people learn. This research yielded general principles about learning that can guide our perspectives of counseling graduate students. According to Bransford, Brown, and Cocking (2000), our students are learning from birth and are more likely to learn what they think is relevant to their lives (Ambrose, Bridges, DiPietro, Lovett, \& Norman, 2010). We must make students aware of the relevance of our lectures and classroom activities in their lives and to their work with clients. Students also learn by connecting previous knowledge to new knowledge (Wlodkowski \& Ginsberg, 2017). Our students may come into our classrooms having had full and successful careers in other fields. We must help them connect that knowledge to their clinical work. For example, we have stay-at-home moms entering our program believing that they have nothing to offer until we highlight the years of practical listening and reflecting skills they have honed over the years with their children.

Additionally, students learn through interaction, as they co-construct knowledge (Barkley \& Major, 2018). We believe learning through interaction parallels what works in therapy: genuine relational interaction. We have found that if at the end of the semester our students can say "We know who Dr. Austin is as a person," they also tend to retain course information. Students also learn when they are engaging in active learning opposed to passively listening to a professor lecture at them (Barkley \& Major, 2018; Wilson \& Korn, 2007). As in the previous principle, joining with students, closing the distance between their 
inexperience and our experience as faculty, engages them in the active learning process. Students' connection to the information often parallels their connections to the instructor.

Our students also learn when we design lectures that minimize cognitive load and lessen the demands on their working memory (Sweller, 2016). Our students' working memories are responsible for temporarily holding information available for processing. While it is essential to reasoning and decision-making, it has a limited capacity. Focus on the quality of the information and experiences with which we load students as opposed to the quantity. We believe every student would prefer a 30-minute lecture and two meaningful and engaging activities compared to 3 hours of a lecture with a 75-slide PowerPoint presentation. Lastly, according to Bjork (2017), our students tend to remember things longer when they have worked hard to learn them by overcoming desirable difficulties. This principle could be taken literally, causing you to make your classes harder to pass. However, we think of ways we can engage our students in a more challenging way during class. This may be done by creating inventive ways for students to process the course topics in small groups. Bjork (2017) suggested that counselor educators address this principle by raising their standards in the class and discussing this rise with students.

\section{What Do They Need to Learn?}

On one hand, students need to learn how to be the counselors we would feel comfortable allowing our loved ones to work with. On the other hand, we want them to pass the licensure exam. Sometimes, a counselor who can do both is difficult to develop. All counseling courses, especially courses in CACREP-accredited programs, focus on specific empirically based skills, knowledge, and 
attitudes needed to conduct effective counseling. To better answer this section's question, we need to know what makes counseling effective. By now it is no secret that for therapy to work, counselors must be proficient at developing a strong therapeutic relationship (Duncan et al., 2010).

The most accepted understanding of how to build a strong therapeutic relationship was developed and proven by Carl Rogers. He suggested that the therapeutic relationship was built upon the therapist's offered conditions of genuineness, unconditional positive regard, and empathy (Rogers, 1951). However, shortly before his death, Rogers said that by paying so much attention to these offered conditions, he ignored the most important element of effective therapy-being therapeutically present with clients (Austin \& Austin, 2018; Baldwin, 2013). Other researchers confirmed the therapist's presence as an essential component of a strong therapeutic relationship (Geller \& Greenberg, 2002; Hayes \& Vinca, 2011). Further research found that successful therapeutic outcomes increased when clients experienced their therapist as being more therapeutically present in session (Geller, Greenberg, \& Watson, 2010). The ability to be therapeutically present in session is like a muscle that can be trained (Austin \& Austin, 2018; Geller, 2017). The operational definition of therapeutic presence should be scaffolded into students' education. We have created a definition geared more toward beginning counseling students, which identifies therapeutic presence as

the way in which students use their self-awareness, awareness of their client, and their awareness of the therapeutic relationship to sense what is needed from moment to moment during session. Once students sense what is needed in a moment, they intentionally use their awareness and skills therapeutically to facilitate their client's healing in that moment (Austin \& Austin, 2018, p. 493). 
As students work toward building their therapeutically present muscles in session, their understanding of therapeutic presence may fit with a more advanced definition of therapeutic presence developed by Geller and Greenberg (2002), who defined therapeutic presence as more than being congruent, real, accepting, empathetic, or responsive; it "involves bringing one's whole self into the encounter with the client, being completely in the moment on a multiplicity of levels, physically, emotionally, cognitively and spiritually" (pp. 82-83).

Learning to be therapeutically present encapsulates the offered conditions (Rogers, 1951) and the skills, knowledge, and attitudes identified by the CACREP. We discuss ways to train students to be more therapeutically present throughout the book. For more information about therapeutic presence, refer to Austin and Austin (2018), Geller (2017), Geller and Porges (2014), and Colosimo and Pos (2015).

\section{The Role of the Counselor Educator in the Classroom}

It is largely your responsibility to help students develop the previously mentioned skills, knowledge, and attitudes required to do effective counseling and pass their licensure exams. In the classroom, we do this by creating an environment that facilitates learning. This process must be flexible to meet a wide variety of students' needs. This task will require all of you-your identity, education, classroom experience, and clinical experience.

Eriksen and McAuliffe (2001) offered suggestions for counselor educators finding their role in the classroom, including the following: (a) encourage expression of conflict, (b) show commitment in the face of doubt, (c) question categorical thinking, (d) process interpersonal dynamics and metacognition awareness, (e) personalize 
teaching, (f) value and promote experience, (g) vary structure, and (h) emphasize multiple perspectives.

To follow their suggestions, the therapeutic relationship between you and your students must be strong. Trust is the key ingredient of a classroom that is willing to be vulnerable enough to confront one another. Trust is especially needed when processing interpersonal dynamics and metacognitions. The role of the counselor educator is explored in greater depth throughout the book. Practical examples of how to follow Eriksen and McAuliffe's (2001) suggestions are also discussed throughout the following chapters.

\section{Developing the Syllabus}

The syllabus, like the intake paperwork during an initial counseling session, may be the first chance students get to build a strong relationship with you and the course. It needs to be written for and to the students, not at the students. By now, you may already know the general purpose of a syllabus. It is essentially a road map for the course, which includes an introduction to the course, the schedule, class assignments, readings, and activities. However, most universities or colleges have their own unique structure, policies, and verbiage that must be included. In addition to these must-haves, some programs want you to display learning outcomes, policy statements, as well as CACREP standards and key performance indicators. In some cases, typically in clinical courses, the syllabus serves as an informed consent document or a contract that both students and professors honor. In fact, after Jude served on a grievance committee, most issues were resolved after the committee looked at and interpreted the course's syllabus. It is important to be intentional when creating and following a syllabus. 
A syllabus is typically 5 to 10 pages long depending upon the attachments you may need to include, such as rubrics or assignment examples. According to Grunert (1997), some learning-centered syllabi stretch up to 30 to 50 pages. This type of syllabi includes things such as notetaking, readings, study material, writing style suggestions, and/or exam study guide information. Syllabi should be tailored to fit the class. While we cannot give you an example of a universal syllabus because each program and university are unique, we can provide suggestions to consider when formulating or updating your course syllabus. The following are essential syllabus items:

- Your name, title, office hours, location, contact information, and a professional website. If students cannot meet face-to-face, provide personal cell phone numbers or video calling options. We encourage caution when providing students with personal contact information. Place limitations around contacting you using personal numbers by outlining specific days and hours you will answer. This can potentially stop students from contacting you 24-7.

- Course information such as meeting times and location, required and suggested texts, any materials needed, links to specific videos, or the course LMS (learning management system).

- A detailed description of the course assignments. This is probably one of the most important elements of the syllabus. As students, we bypassed everything and looked for the assignments. The more details added into the description of the assignments can decrease the questions from students. We also add specifics about our expectations. For example, we have added specifics about page limits on 
written assignments — even going far enough to take off percentage points for papers longer than the requirement. Outline ungraded assignments such as practice quizzes or paper drafts. If you plan to grade class participation, your expectations for participation need to be outlined as well.

- Student learning outcomes need to be outlined. They are a list of things your students should be able to do by the end of the course. As students, we did not care about these outcomes, but they are important to us as faculty because often our teacher evaluations are tied to these learning outcomes. More than outlining them in the syllabus, they should be discussed in class throughout the semester.

- A breakdown of the grading scale and the weight of each assignment's grade on the course grade needs to be outlined. Explain the grading system with percentage breakdowns.

- Explanation of policies regarding late work, revisions, or failure to submit work.

- Policies on attendance and tardiness should be outlined. We found this to be particularly important in clinical skills classes that students need to attend so that all students can have opportunities to participate.

- Academic honesty policy should be outlined and also how you plan to check written work for plagiarism. Some universities provide ways to do this via the course's online shell.

- Your university may require you to outline their policies on Americans with Disabilities Act (ADA) accommodations. Students may reach out to discuss their specific accommodations and would like to personalize their experience in the course. 
- A section outlining classroom culture, professionalism, and academic discourse. When working with a new cohort, we sometimes dedicate a piece of the first class to discussing what it means to be a graduate student. We discuss the difference between undergraduate and graduate classrooms and their role in creating a safe learning environment, defining what a safe classroom is, and things students can do to avoid making other students uncomfortable.

- A detailed, week-by-week course schedule identifying the topics, readings, and assignments due on each day.

\section{Assessments: Students' Learning and Your Performance}

There are two different kinds of assessments: summative and formative evaluations. Summative evaluations happen at the end of a semester, whereas formative evaluations occur before the end so that we can practice and refine the curriculum before the summative evaluation. According to Lau (2016), one is not better than the other. Creating a system where they work together is ideal. The combination of the two evaluations are more effective if the assessments are connected to each other and the learning process, students buy into the learning process and want to improve, and the relationship is strong between students and professor. The goal of assessments is to facilitate and track learning. In this evaluation process, clearly defined and discussed learning objectives are vital to receiving useful feedback about the course. There is a greater discussion regarding course and program evaluations, including ways to evaluate learning and performance in each course, throughout the book. 


\section{SUMMARY}

In our lives as counselor educators, we assume many roles and responsibilities. These roles and responsibilities can make it feel like we are working 24-7. There is always a student emailing at 3:00 a.m., or a book chapter due, or a deadline to meet, or accreditation to prepare for, or students to meet. When entering our first faculty positions, feelings of unpreparedness, fear, and incongruence overwhelmed us. It can sometimes feel like students smell fear and the classroom environment focuses our inadequacies to a sharp edge for 6 to 9 hours a week. Effectively managing these roles and responsibilities comes with experience, with more experience comes different roles and responsibilities, and the cycle continues. Within these role and responsibilities, counselor educators have a unique opportunity to impact their communities through one interaction with a student. One moment of genuine sharing of a clinical thought can have a positive ripple effect in the lives of our students' clients. Our hope is that in this chapter you saw the challenges and potential of this profession. We go into greater detail regarding the topics discussed in this chapter throughout the book.

\section{REFERENCES}

Aliakbari, M., \& Faraji, E. (2011). Basic principles of critical pedagogy. Second international conference on humanities, historical and social sciences. IPEDR, 17, 78-85. Retrieved from http://www.ipedr.com/vol17/ 14-CHHSS\%202011-H00057.pdf

Altbach, P. G. (2015). The Carnegie classification of American higher education: More-and less-than meets the eye. International Higher Education, (80), 21-23. doi:10.6017/ ihe.2015.80.6153

Ambrose, S. A., Bridges, M. W., DiPietro, M., Lovett, M. C., \& Norman, M. K. (2010). How learning works: Seven 
research-based principles for smart teaching. San Francisco, CA: John Wiley \& Sons.

Association for Counselor Education and Supervision. (n.d.). About ACES. Retrieved from https:/ / acesonline.net/ about-aces

Association for Counselor Education and Supervision. (1979). Standards for preparation in counselor education. Falls Church, VA: American Personnel and Guidance Association.

Association for Counselor Education and Supervision. (2014). Statement on educational standards for counselor licensure. Alexandria, VA: Author

Austin, J. T., \& Austin, J. A. (2018). Initial exploration of therapeutic presence pedagogy in counselor education. International Journal for the Advancement of Counselling, 40, 481-500. doi:10.1007/s10447-018-9339-x

Baldwin, M. (2013). The use of self in therapy. New York, NY: Routledge.

Baltrinic, E. R., Jencius, M., \& McGlothlin, J. (2016). Coteaching in counselor education: Preparing doctoral students for future teaching. Counselor Education and Supervision, 55(1), 31-45. doi:10.1002/ceas.12031

Barkley, E. F., \& Major, C. H. (2018). Interactive lecturing: A handbook for college faculty. San Francisco, CA: John Wiley \& Sons.

Barrio Minton, C. A., Wachter Morris, C. A., \& Yaites, L. D. (2014). Pedagogy in counselor education: A 10-year content analysis of journals. Counselor Education and Supervision, 53(3), 162-177. doi:10.1002/j.15566978.2014.00055.x

Bjork, R. A. (2017). Creating desirable difficulties to enhance learning. In I. Wallace \& L. Kirkman (Eds.), Best of the best: Progress (pp. 81-85). Carmarthen, UK: Crown House Publishing.

Bransford, J. D., Brown, A. L., \& Cocking, R. R. (Eds.). (2000). How people learn (Vol. 11). Washington, DC: National Academies Press.

Colosimo, K. A., \& Pos, A. E. (2015). A rational model of expressed therapeutic presence. Journal of Psychotherapy Integration, 25(2), 100-114. doi:10.1037/a0038879

Council for Accreditation of Counseling and Related Educational Programs. (2001). 2001 standards. Alexandria, VA: Author. 
Council for Accreditation of Counseling and Related Educational Programs. (2009). 2009 standards. Alexandria, VA: Author.

Council for Accreditation of Counseling and Related

Educational Programs. (2015a). 2016 CACREP standards.

Retrieved from http:/ /www.cacrep.org/wp-content/ uploads/2017/08/2016-Standards-with-citations.pdf

Council for Accreditation of Counseling and Related Educational Programs. (2015b). About CACREP. Retrieved from https:/ /www.cacrep.org/about-cacrep Council for Accreditation of Counseling and Related Educational Programs. (2020). About CACREP. Retrieved from https: / / www.cacrep.org/about-cacrep/

Duncan, B. L., Miller, S. D., Wampold, B. E., \& Hubble, M. A. (2010). The heart and soul of change: Delivering what works in therapy. Washington, DC: American Psychological Association.

Elliott, A., Salazar, B. M., Dennis, B. L., Bohecker, L., Nielson, T., LaMantia, K., \& Kleist, D. M. (2019). Pedagogical perspectives on counselor education: An autoethnographic experience of doctoral student development. The Qualitative Report, 24(4), 648-666. Retrieved from https:/ / nsuworks.nova.edu/tqr/vol24/iss4/2

Eriksen, K., \& McAuliffe, G. (Eds.). (2001). Teaching counselors and therapists: Constructivist and developmental course design. Westport, CT: Bergin \& Garvey/Greenwood.

Freire, P. (2018). Pedagogy of the oppressed. New York, NY: Bloomsbury Publishing.

Geller, S. M. (2017). A practical guide to cultivating therapeutic presence. Washington, DC: American Psychological Association.

Geller, S. M., \& Greenberg, L. S. (2002). Therapeutic presence: Therapists' experience of presence in the psychotherapy encounter. Person-Centered and Experiential Psychotherapies, 1(1-2), 71-86. doi:10.1080/14779757.2002.9688279

Geller, S. M., Greenberg, L. S., \& Watson, J. G. (2010). Therapist and client perceptions of therapeutic presence: The development of a measure. Psychotherapy Research, 20(5), 599-610. doi:10.1080/10503307.2010.495957

Geller, S. M., \& Porges, S. W. (2014). Therapeutic presence: Neurophysiological mechanisms mediating feeling safe in therapeutic relationships. Journal of Psychotherapy Integration, 24(3), 178-188. doi:10.1037/a0037511 
Gregg, G. S. (2017). Social values and moral intuitions: The world-views of "millennial" young adults. New York, NY: Routledge.

Grunert, J. (1997). The course syllabus: A learning-centered approach. Bolton, MA: Anker Publishing Company.

Hayes, J., \& Vinca, J. (2011). Therapist presence and its relationship to empathy, session, depth, and symptom reduction. Bern, Switzerland: Society for Psychotherapy Research.

Knowles, M. S. (1970). Gearing adult education for the seventies. The Journal of Continuing Education in Nursing, 1(1), 11-16. Retrieved from https:/ / eric. ed.gov /?id=EJ024167

Lau, A. M. S. (2016). 'Formative good, summative bad?'-A review of the dichotomy in assessment literature. Journal of Further and Higher Education, 40(4), 509-525. doi:10.108 0/0309877X.2014.984600

Magnuson, S. (2002). New assistant professors of counselor education: Their 1st year. Counselor Education and Supervision, 41(4), 306-320. doi:10.1002/j.1556-6978.2002 .tb01293.x

Malott, K. M., Hall, K. H., Sheely-Moore, A., Krell, M. M., \& Cardaciotto, L. (2014). Evidence-based teaching in higher education: Application to counselor education. Counselor Education and Supervision, 53(4), 294-305. doi:10.1002/ j.1556-6978.2014.00064.x

McAuliffe, G., \& Eriksen, K. (Eds.). (2011). Handbook of counselor preparation: Constructivist, developmental, and experiential approaches. Thousand Oaks, CA: Sage.

Mezirow, J. (2018). Transformative learning theory. In K. Illeris (Ed.), Contemporary theories of learning: Learning theorists (pp. 114-128). New York, NY: Routledge.

Nixon-Ponder, S. (1995). Using problem-posing dialogue: In adult literacy education. Adult Learning, 7(2), 10-12. Retrieved from https://www.researchgate. net/publication/234598591_Using_Problem-Posing Dialogue_In_Adult_Literacy_Education

Okech, J. E. A., \& Rubel, D. J. (Eds.). (2018). Counselor education in the 21st century: Issues and experiences. San Francisco, CA: John Wiley \& Sons.

Orr, J. J., Hall, S. F., \& Hulse-Killacky, D. (2008). A model for collaborative teaching teams in counselor education. 
Counselor Education and Supervision, 47(3), 146-163. doi:10.1002/j.1556-6978.2008.tb00046.x

Palmer, P. J. (2017). The courage to teach: Exploring the inner landscape of a teacher's life. San Francisco, CA: John Wiley \& Sons.

Rogers, C. R. (1951). Client-centered therapy. Boston, MA: Houghton Mifflin.

Skovholt, T. M., \& Ronnestad, M. H. (1992). Themes in therapist and counselor development. Journal of Counseling and Development, 70(4), 505-515. doi:10.1002/j .1556-6676.1992.tb01646.x

Stewart, K. D., \& Bernhardt, P. C. (2010). Comparing Millennials to pre-1987 students and with one another. North American Journal of Psychology, 12(3), 579-602. Retrieved from https:/ /www.researchgate.net/ publication/230683045_Comparing_Millennials_to_pre -1987_students_and_with_one_another

Sweller, J. (2016). Cognitive load theory, evolutionary educational psychology, and instructional design. In D. Geary \& D. Berch (Eds.), Evolutionary perspectives on child development and education (pp. 291-306). Cham, Switzerland: Springer Publishing Company.

Vijaya Kumari, S. N. (2014). Constructivist approach to teacher education: An integrative model for reflective teaching. Journal on Educational Psychology, 7(4), 31-40. doi:10.26634/jpsy.7.4.2655

Whitman, J. S., \& Beeson, E. T. (2018). Developing a personal philosophy of teaching. In L. R. Haddock \& J. S. Whitman (Eds.), Preparing the educator in counselor education (pp. 26-46). New York, NY: Routledge.

Wilson, K., \& Korn, J. H. (2007). Attention during lectures: Beyond ten minutes. Teaching of Psychology, 34(2), 85-89. doi:10.1080/00986280701291291

Wlodkowski, R. J., \& Ginsberg, M. B. (2017). Enhancing adult motivation to learn: A comprehensive guide for teaching all adults. Hoboken, NJ: John Wiley \& Sons. 